\title{
La importancia del curado en el comportamiento posterior frente a la corrosión de las estructuras de hormigón armado
}

\section{The significance of curing in the future corrosion resistance of concrete structures}

\section{$R E S U M E N$}

Cuando el acero se pone en contacto con el hormigón fresco, debido a la naturaleza alcalina de éste, el acero se recubre de una capa de óxidos pasivantes, que lo mantienen constantemente protegido. En este proceso juega un papel preponderante la presencia del oxigeno, que resulta también esencial para el desarrollo de los procesos de corrosión, cuando hay agresivos presentes (por ejemplo los cloruros).

En el presente trabajo se comentan resultados de los cambios que se aprecian, tanto en el proceso de pasivación como de corrosión, cuando el acceso de oxígeno se limita, circunstancia que se produce cuando el hormigón se cura en condiciones de saturación de agua.

Los resultados muestran que la disponibilidad de oxígeno durante el curado tiene una marcada influencia en la resistencia futura a la corrosión lo, que indica que los mecanismos no son tan evidentes como se pensaba y se necesitarán ensayos futuros específicos para aclarar todos los aspectos que ahora aparecen como contradictorios.

\section{$S \cup M M A R Y$}

Steel in contact with fresh concrete is covered by a layer of passivating oxydes due to the alkaline nature of the pore solution. The presence of oxygen plays an important role in this passivation process as well as in the corrosion one when is developped due to the ingress of aggressives, such as, chloride ions.

In the present paper, results are commented on the behaviour found when oxygen is limited due to the concrete curing conditions, in a completely saturated chamber.

Surprisely, the results indicate that the oxygen availability during the curing has a marked influence on the future corrosion beabieviour. This allows to deduce that the mechanisms involved are not so simple as was currently accepted and that new specific tests are needed to clarify the controversial points.

\section{INTRODUCCIÓN}

Es ampliamente reconocido que la corrosión representa un grave problema económico. Estudios realizados en varios países [1] cifran los costes directos de la corrosión entre el 1,25 y el $4 \%$ del PIB de un país.

También se reconoce que uno de los sectores con mayores pérdidas es el de la Construcción,

\section{INTRODUCTION}

Corrosion is known to give rise to serious economic problems. In fact, direct costs incurred as a result are estimated to account typically for 1.25-4\% of the GDP of a developed country [1].

The problems associated with corrosion are felt particularly strongly by the building sector in the

\footnotetext{
(1) Universidad Nacional Autónoma de México

(2) CENIMUCSIC. ESPAÑA

(3) ICCET/CSIC. ESPAÑA.
} 
debido a que los costes de reparación de las estructuras de hormigón armado son muy elevados, aparte de las implicaciones sociales aunadas a los fallos de este tipo de estructuras.

En el curso de una investigación mucho más amplia, se contemplan esencialmente los aspectos siguientes:

1) El efecto de la temperatura bajo diferentes condiciones de agresividad del medio y su relación con la velocidad de corrosión de las armaduras, $y$

II) El mecanismo de iniciación y propagacióon de la corrosión en este tipo de estructuras.

Se comprobó que diferencias, aparentemente nimias, en las condiciones de curado, tenían luego un gran efecto en la velocidad de corrosión de las armaduras.

El objeto de la presente comunicación es analizar este comportamiento inesperado, que puede tener repercusiones prácticas muy importantes en la durabilidad de las estructuras de hormigón armado.

\section{PROCEDIMIENTO EXPERIMENTAL}

En la investigación se utilizaron probetas de mortero de $2 \times 5,5 \times 8 \mathrm{~cm}$, similares a las empleadas en muchos trabajos anteriores [2-4], en las que se embebían dos redondos de acero para armar en posiciones simétricas, con un electrodo central de grafito, o de acero inoxidable, que servía para imponer las señales eléctricas en el momento de realizar las medidas (figura 1).

Las probetas se fabricaron con una relación cemento/arena/agua $=1 / 3 / 0,5$ y con adiciones de $0,2,4$ y $6 \%$ de $\mathrm{Cl}^{-}$(como NaCl). Una vez desenmoldadas se curaron durante 40 días en una cámara de vapor de agua sobresaturado a $23^{\circ} \mathrm{C}$, que producía una condensación continua de agua sobre la superficie del mortero, en el ICCET. Como no se podía introducir la instrumentación en la cámara de vapor, algunas probetas se curaron en el CENIM, sobre agua, en pequeños recipientes, con una $\mathrm{HR}>90 \%$, impuesta por la presión de vapor de $\mathrm{H}_{2} \mathrm{O}$ a la temperatura ambiente.

Se realizó un control del potencial de corrosión, $E_{\text {corr }}$, de la velocidad instantánea de corrosión a través de la medida de la resistencia de polarización, $\mathrm{Rp}$, de la resistividad, porosidad y pérdida de agua del mortero, y de la impedancia electroquímica de la interfase acero/mortero, para tratar de discernir las posibles causas de las variaciones tan grandes en la cinética del proceso. form of costs involved in repairing damaged concrete structures and in compensations for failures of this type of structures.

Comprehensive research on the effect of temperature under different aggressive environmental conditions and its relationship to the corrosion rate of reinforcements, and on the mechanism of initiation and propagation of corrosion in this type of structures revealed that seemingly insignificant differences in the curing conditions had a deferred marked effect on the rate of corrosion of the reinforcements.

The aim of this work was to analyse this unexpected behaviour, which may have major practical consequences on the durability of concrete structures.

\section{EXPERIMENTAL}

Research was conducted on $2 \times 5.5 \times 8 \mathrm{~cm}$ mortar specimens similar to those used in previous works [2-4] and in which two reinforced steel rods were embedded in symmetric positions together with a central graphite or stainless steel electrode that was used to apply electrical signals at the time of making measurements (Fig. 1).

The specimens were prepared in a cement/sand/water ratio of $1: 3: 0.5$ and were added 0, 2, 4 or $6 \% \mathrm{Cr}$ (such as $\mathrm{NaCl}$ ). Once cast out, they were cured for 40 days in an oversaturated water vapour atmosphere (steam chamber), that produced continuous condensation on the mortar surface, at the ICCET. Because the instrumentation could not be placed in the steam chamber, some mortar specimens were cured in small vessels with water $(R H>90 \%$, imposed by the water vapor pressure at room temperature) at CENIM.

Such parameters as the corrosion potential $\left(E_{\text {corr }}\right)$, the instantaneous corrosion rate (measured via the polarization resistance, $R_{\rho}$, the mortar resistivity, porosity and loss water, and the electrochemical impedance of the steel/mortar interfase were monitored throughout the time in order to establish the potential causes of the very different kinetics of the corrosion process. 


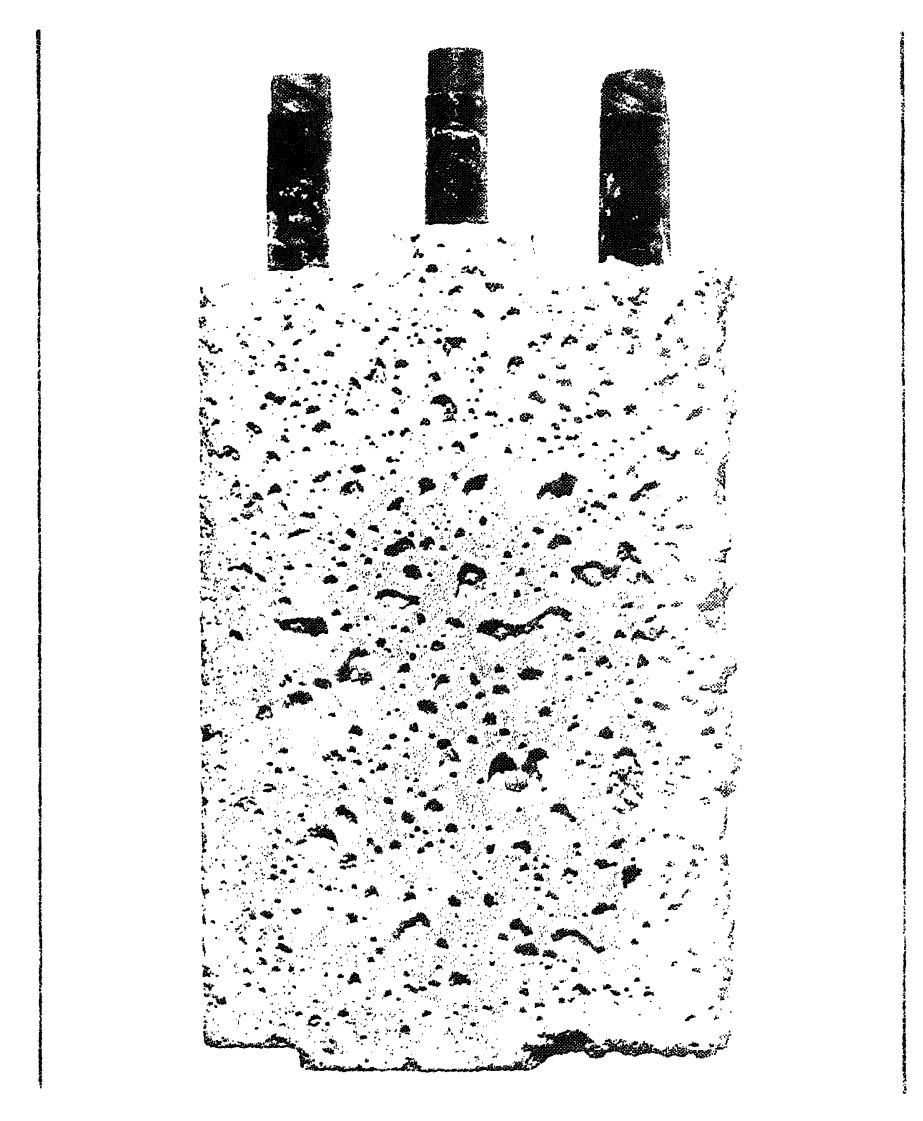

Fig. 1.-Fotografía de las probetas de mortero utilizadas.

Fig. 1. - Photograph of mortar specimens used.

\section{RESULTADOS EXPERIMENTALES}

Curado en atmósfera con HR > $90 \%$, impuesta por la presión de vapor del $\mathrm{H}_{2} \mathrm{O}$ a temperatura ambiente (Cámara húmeda)

Las figuras $2 a$ y 3 a muestran los resultados del comportamiento frente a la corrosión de los redondos de acero en morteros sin adiciones de cloruros y con un $2 \%$ de $\mathrm{Cl}^{-}$, respectivamente. Las concentraciones del 4 y $6 \%$ de $\mathrm{Cl}^{-}$mostraron evoluciones similares a la del $2 \%$.

En las gráficas $2 b$ y $3 b$ se representa la variación del $E_{\text {corr }}$ durante el curado y en las $2 c$ y $3 c$ la de la resistividad del mortero, medida con una corriente alterna de $1 \mathrm{KHz}$.

\section{Curado en atmósfera de vapor sobresaturado y condensación de $\mathrm{H}_{2} \mathrm{O}$ a $23^{\circ} \mathrm{C}$ (Cámara de vapor)}

La figura 4 ofrece la misma información que las figuras 2 y 3 para las probetas curadas con condensación de $\mathrm{H}_{2} \mathrm{O}$ sobre la superficie del mortero, después de sacarlas de la cámara de vapor a los 40 días de curado.

\section{EXPERIMENTAL RESULTS}

Curing at a $\mathrm{RH}>90 \%$ atmosphere, imposed by water vapour pressure at room temperature (wet chamber).

Figures 2a and 3a illustrate the corrosion behaviour of the steel rods embedded in the mortar specimens with no chloride added and with $2 \% \mathrm{Cr}$, respectively. The mortars with 4 and $6 \%$ Cl provided similar results to that containing only $2 \% \mathrm{Cr}$.

On the other hand, figures $2 b$ and $3 b$ show the variation of $E_{\text {corr }}$ during the curing process, while Figs. $2 c$ and $3 c$ show the changes in mortar resistivity as measured by applying an alternating current of $1 \mathrm{kHz}$.

\section{Curing in a oversaturated water vapor atmosphere with $\mathrm{H}_{2} \mathrm{O}$ condensation at $23^{\circ} \mathrm{C}$ (steam chamber).}

Figure 4 provides the same information as Figs. 2 and 3 , but on the specimens cured by water condensation on the mortar surface once removed from the steam chamber after 40 day's curing. 


\section{EFECTO DEL CURADO \\ O\% DE Cl}

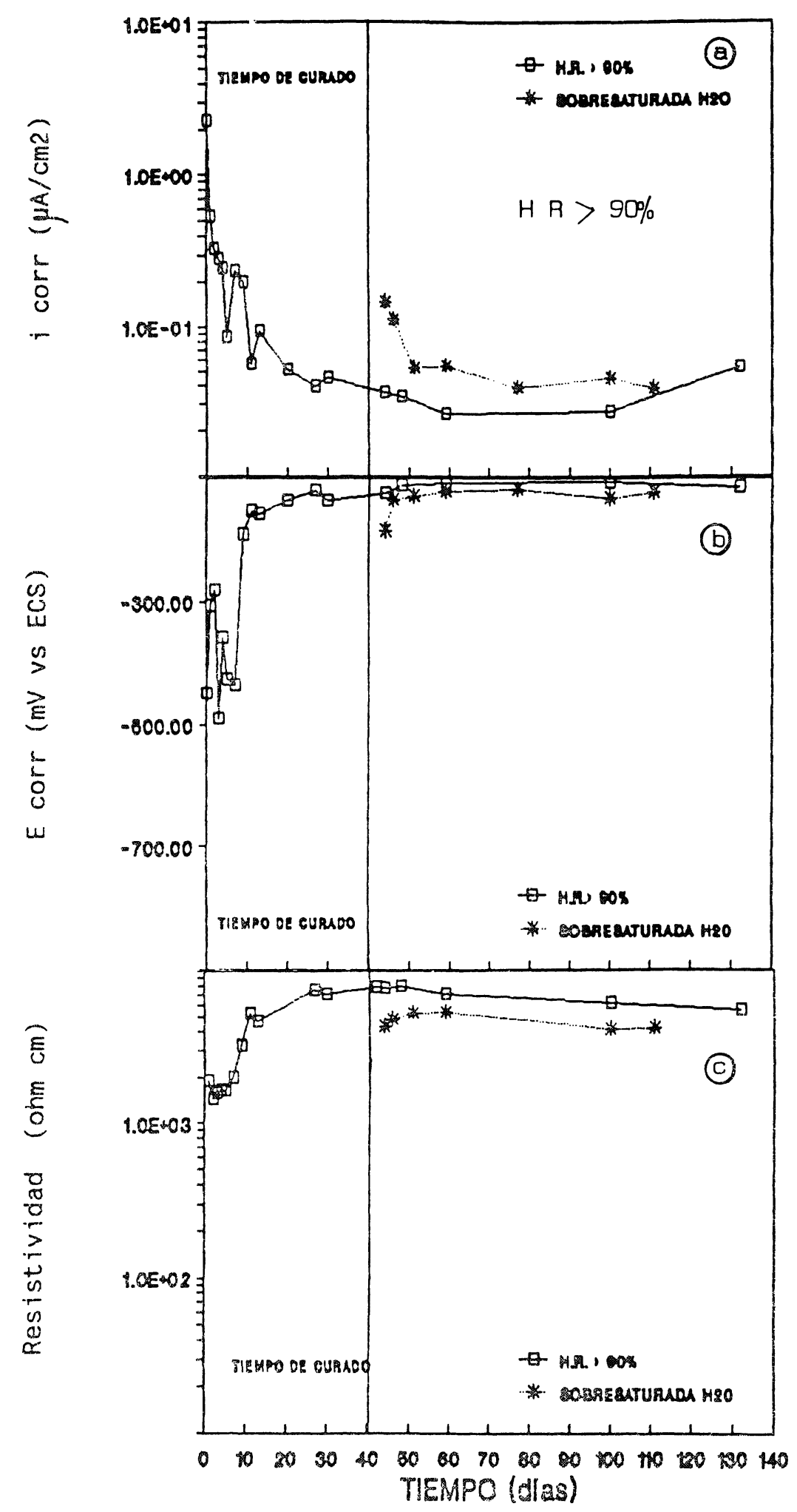

CENIM

Fig. 2.--Comparación del comportamiento frente a la corrosión de probetas de mortero sin cloruros curadas en atmósfera con HR > $90 \%$ (cámara húmeda) y en atmósfera sobresaturada de vapor de agua (cámara de vapor).
Fig. 2.-Comparison between corrosion behaviour of mortar specimens without $\mathrm{Cr}$ cured at $\mathrm{RH}>90 \%$ atmosphere (wet chamber) and in an oversatured water vapour atmosphere (steam chamber). 


\section{EFECTO DEL CURADO \\ $2 \% \mathrm{Cl}$}

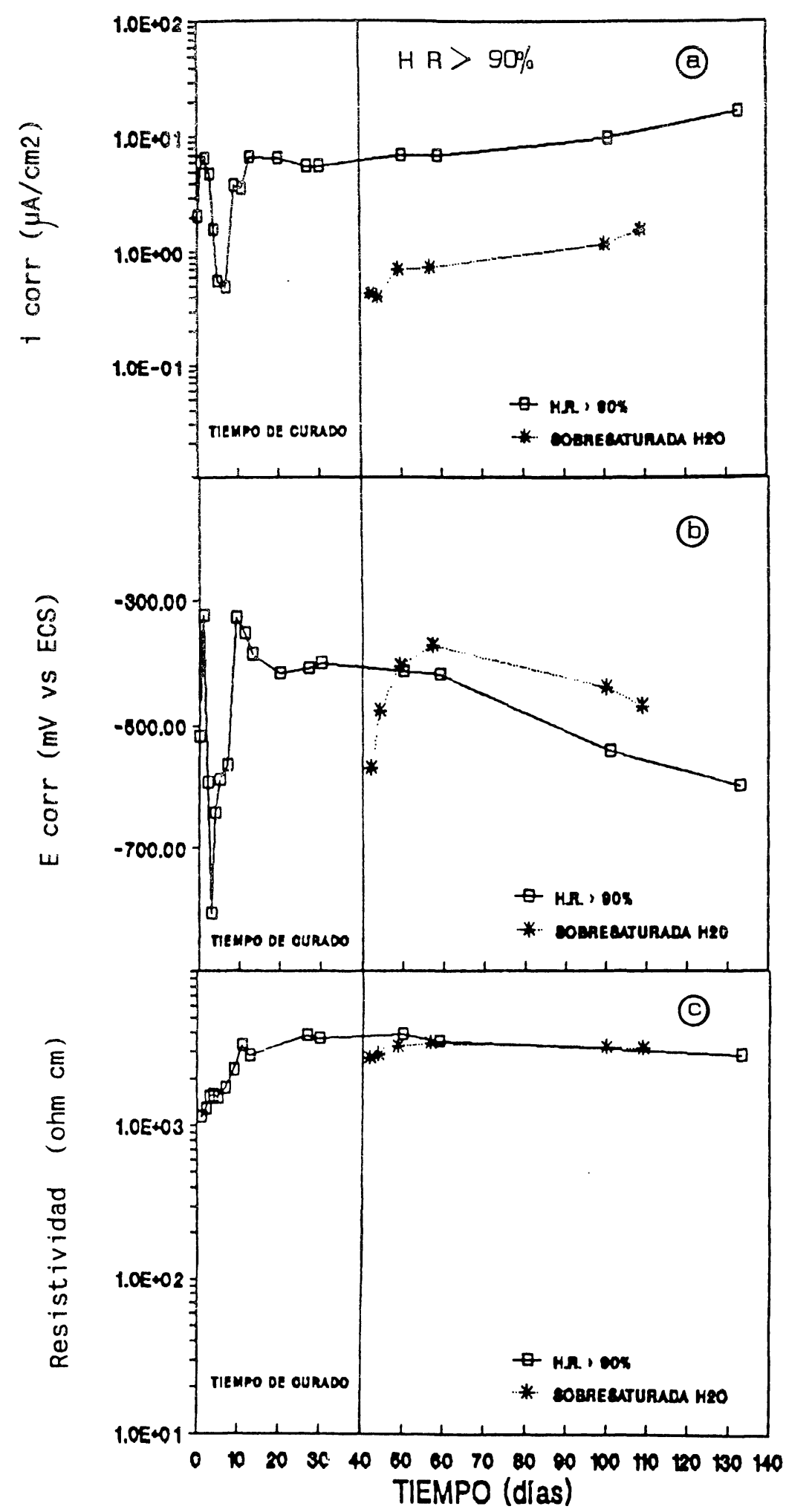

CENMM

Fig. 3.-Comparación del comportamiento frente a la corrosión de probetas de mortero con un $2 \% \mathrm{Cl}^{-}$, curadas en atmósfera con HR > $90 \%$ (cámara húmeda) y en atmósfera sobresaturada de vapor de agua (cámara de vapor).
Fig. 3.-Comparison between corrosion behaviour of mortar specimens containing $2 \% \mathrm{Cr}$, cured at a $\mathrm{RH}>90 \%$ atmosphere (wet chamber) and in an oversatured water vapour atmosphere (steam chamber). 


\section{EFECTO DEL CURADO \\ ATMÓSFERA SOBRESATURADA DE H2O}

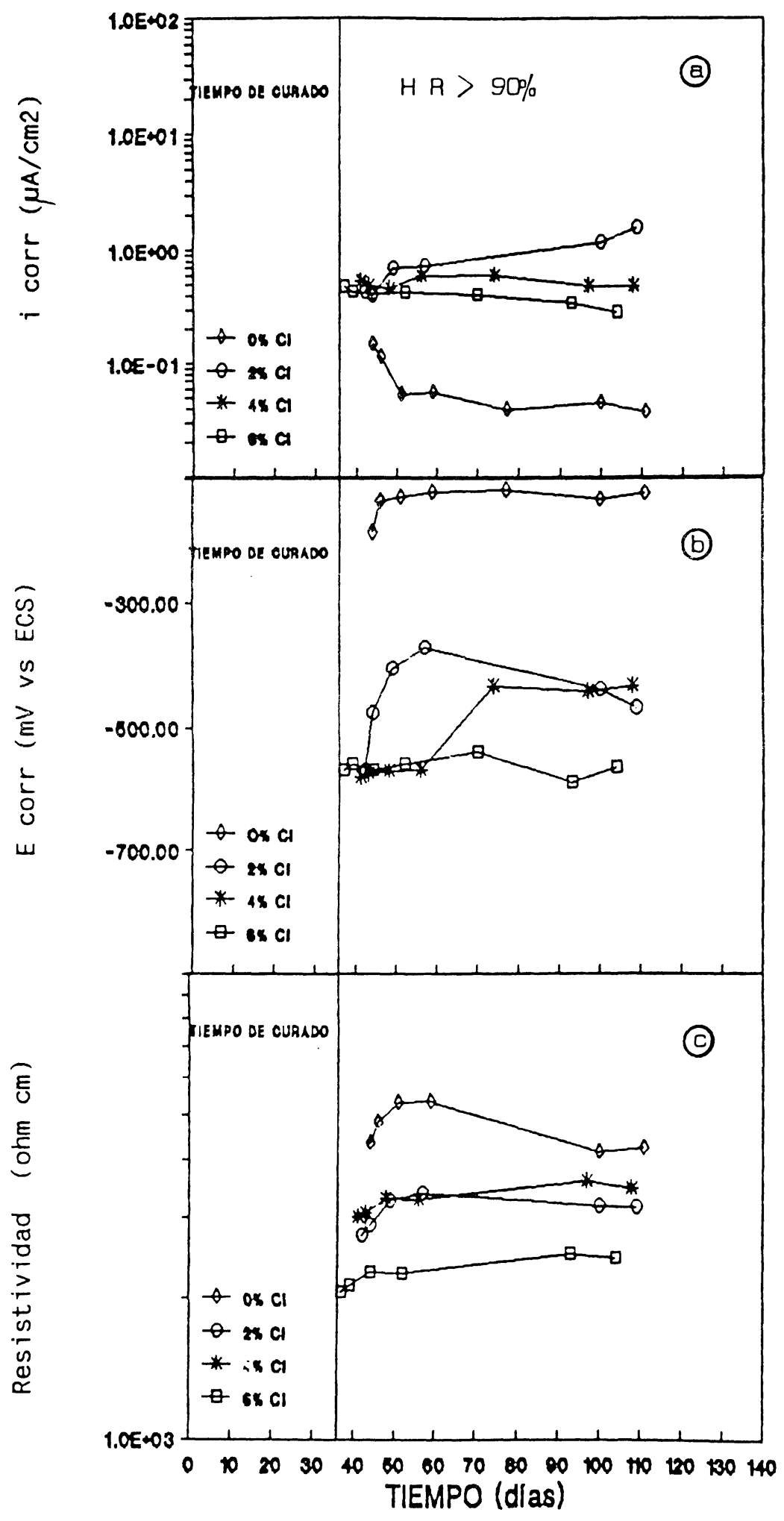

CENM

Fig. 4. - Comportamiento frente a la corrosión de probetas de mortero, con distintos contenidos en cloruros, curadas en atmósfera sobresaturada de vapor de agua (cámara de vapor) y trasladadas a una cámara con HR $>90 \%$.
Fig. 4.-Corrosion behaviour of mortar specimens with different $\mathrm{Cr}$ content, cured in a water vapour atmosphere (steam chamber) and trasferred to a RH > $90 \%$ chamber. 

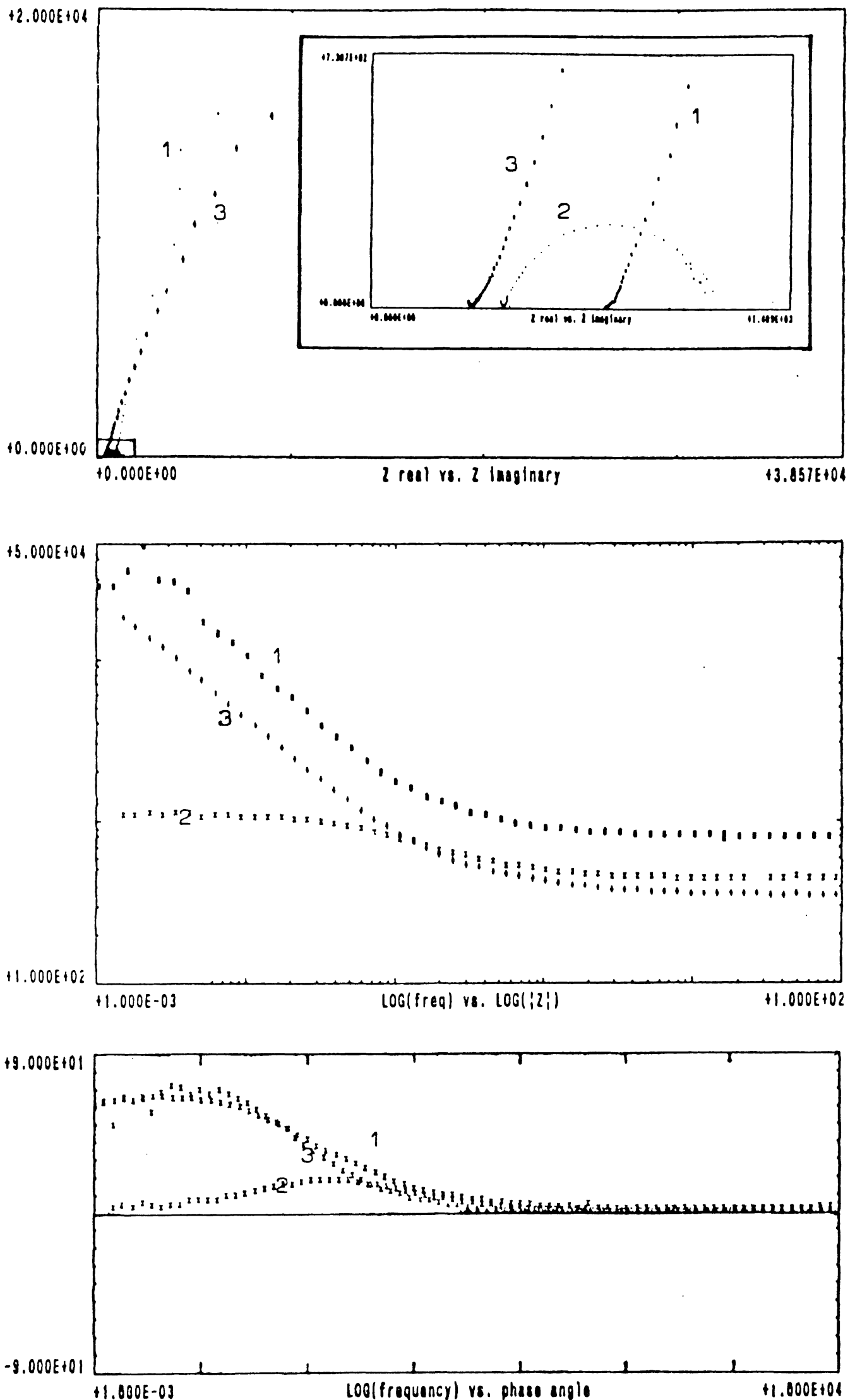

Fig. 5.-Respuesta de la impedancia electroquímica en morteros con $0 \% \mathrm{Cl}^{-}(1)$ y $2 \% \mathrm{Cl}^{-}(2,3)$ y curados en HR > $90 \%(1,2)$ y en atmósfera sobresaturada de vapor de agua (3), respectivamente.
Fig. 5.-Responce of the electrochemical impedance of mortars containing $0 \%(1)$ and $2 \%(2,3) \mathrm{Cr}$, and cured at $R H>90 \%(1,2)$ and in a oversaturated water vapour atmosphere (3), respectively. 


\section{Diagrama de impedancia de la interfase acero-mortero}

Como las medidas de Rp no ofrecen suficiente información sobre el mecanismo de corrosión, por esta razón se realizaron también ensayos de impedancia electroquímica y en la figura 5 se incluyen los resultados obtenidos para los dos tipos de curado, en el caso del mortero con la adición de un $2 \%$ de $\mathrm{NaCl}$, que se comparan con el diagrama correspondiente a una probeta sin cloruros y curada en cámara húmeda, después de un tiempo de 65 días de fabricación. Pueden observarse dos respuestas sustancialmente distintas, según el tipo de curado, para las probetas con adiciones de cloruros.

\section{Variación de peso de las probetas de mortero}

Después de terminado el curado en la cámara de vapor del ICCET, se trasladaron las probetas al CENIM, introduciéndolas en la cámara húmeda (un desecador con agua en la parte inferior $y$ $\mathrm{HR}>90 \%$ ), conjuntamente con las probetas curadas en ella. Como testimonia la figura 6 , se produce, a partir del momento del trasvase, una cesión de agua significativa de las probetas curadas en cámara de vapor y la captación del agua por parte de las probetas curadas en cámara húmeda, resultados que ponen de manifiesto un grado de saturación de los poros distinto en cada caso.
Impedance diagrams of the steel-mortar interfase

The $R_{p}$ measurements often provide little or no information on corrosion mechanisms. For this reason, we also performed impedance assays, the results of which are reflected in Fig. 5 for the two types of curing on mortars containing $2 \%$ and no $\mathrm{Cr}$, after 65 days of manufacturing. As can be seen, the chloride-containing mortar responsed substantially differently to the two types of curing.

\section{Weight changes in the mortar specimens}

After curing in the steam chamber at ICCET was finished, the mortar specimens were transferred to CENIM, where they were placed in the wet chamber (a desiccator with water in the bottom), together with the specimens previously cured there. As can be seen from Fig. 6, on transferral, the specimens cured in the steam chamber started to release major amounts of water and those cured in the wet chamber began to absorb it, which reveals a difference in pore saturation between the two.

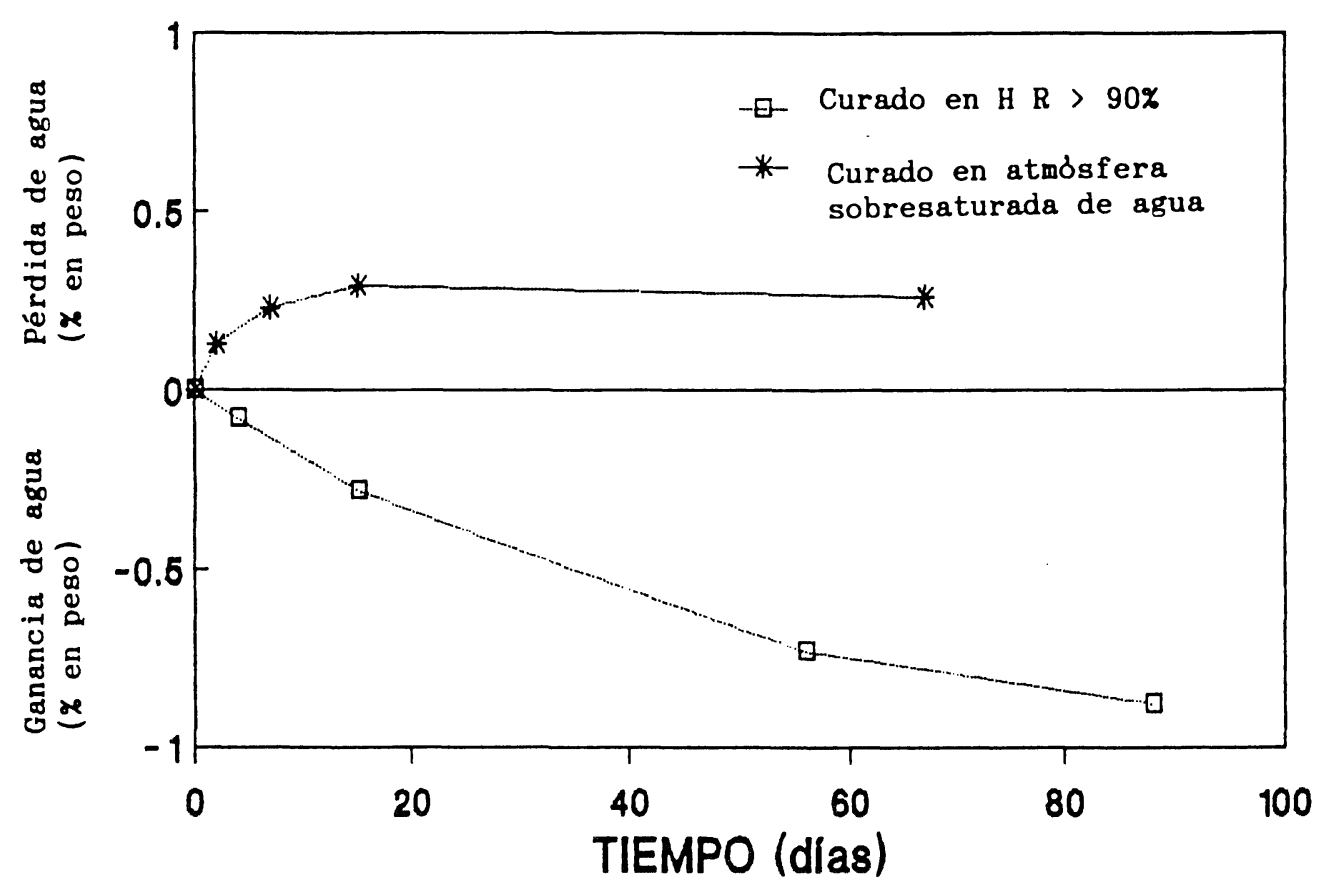

Fig. 6.-Las probetas curadas en cámara de vapor desprenden agua al trasladarlas a una cámara de $\mathrm{HR}>90 \%$, mientras que las curadas a HR > $90 \%$, mezcladas con las anteriores, absorben humedad.
Fig. 6.-Specimens cured in a steam chamber release water on transferral to the chamber with $\mathrm{RH}>90 \%$, while those cured at $R H>90 \%$, mixed with the previous ones, absorbed it. 


\section{Observaciones complementarias}

Al término del curado, las probetas con 2 y $4 \%$ de $\mathrm{Cl}^{-}$, que habían permanecido en cámara húmeda con $\mathrm{HR}>90 \%$, pero sin condensación de $\mathrm{H}_{2} \mathrm{O}$ sobre su superficie, presentaban fracturas siguiendo la dirección del refuerzo metálico y manchas de óxido, que había difundido a través de las grietas, o de algún macroporo que afloraba a la superficie.

Entre las probetas curadas bajo condensación continua de vapor no se detectó ninguna que presentase agrietamiento, ni manchas de óxido. Tampoco se detectaron en ninguna de las probetas con un $6 \%$ de $\mathrm{Cl}^{-}$, aunque hubieran sido curadas en cámara húmeda, si bien eran las únicas de las curadas a $\mathrm{HR}>90 \%$ que presentaban la superficie del mortero continuamente humedecida, a causa de la higroscopicidad del $\mathrm{NaCl}$.

Determinada la porosidad del mortero al término del curado, no se detectaron diferencias significativas entre las probetas curadas en unas $\mathrm{u}$ otras condiciones.

\section{DISCUSIÓN}

En las estructuras de hormigón armado se pueden distinguir las que permanecen en el estado pasivo (sin carbonatar y sin cloruros) de las que se atacan en el estado activo.

En las estructuras pasivas controlan la cinética de corrosión las características de la capa pasivante y las velocidades de corrosión extraordinariamente lentas no plantean ningún problema de durabilidad. Las $i_{\text {corr }}$ suelen ser $<0,1 \mu \mathrm{A} / \mathrm{cm}^{2}$ (figura 2) y dan lugar a penetraciones de la corrosión de 1 mpy, o inferiores.

Para las estructuras que se corroen en estado activo se admitía, hasta hace poco, que la difusión del oxígeno hasta las armaduras establecía el límite superior de la velocidad de deterioro. Sin embargo, están apareciendo en la bibliografía resultados que no admiten explicación satisfactoria por este modelo [4-6], pues se alcanzan $i_{\text {corr }}$ uno o dos órdenes de mágnitud superiores a las que cabría esperar para la $i_{\text {IIm }}$ de difusión del oxígeno en el hormigón.

La figura 3a pone de manifiesto que, en presencia de cloruros, en función del tipo de curado sufrido por las probetas, se establecen dos niveles de velocidades de corrosión bien diferenciados. Las probetas curadas en cámara de vapor exhiben $i_{\text {corr }}$ entre 0,1 y $1,0 \mu \mathrm{A} \mathrm{cm}^{2}$, mientras que a las curadas en cámara húmeda les corresponden, a partir de los 10 días de curado, $i_{\text {corr }}$ del orden de $10 \mu \mathrm{A} / \mathrm{cm}^{2}$, o incluso superiores. Lo cual

\section{Other observations}

At the end of curing, the specimens with 2 and $4 \% \mathrm{Cr}$ which had been kept in the wet chamber at $\mathrm{RH}>90 \%$ but with no water condensation on their surfaces showed fractures in the direction of the metal reinforcement and rust stains as a result of diffusion through cracks or macropores connected with the external surface.

None of the specimens cured under continuous condensation of steam showed any signs of cracks or rust stains. Neither did any of the mortars containing $6 \% \mathrm{Cr}$, whether or not they were cured in the wet chamber, however, these were the only among those cured at $\mathrm{RH}>90 \%$ that showed surface wetness throughout as a result of the hygroscopic character of $\mathrm{NaCl}$.

No significant differences in mortar porosity were detected at the end of curing between the specimens subjected to the different conditions.

\section{DISCUSSION}

Concrete structures can be divided into those which remain in a passive state (uncarbonated and without chloride ions) and those which are attacked in an active state.

In passive structures, the corrosion kinetics is governed by the properties of the passivating layer, and the corrosion rate, extremely low, poses no durability problem. In fact, $i_{\text {corr }}$ values are usually less than $0.1 \mu \mathrm{A} / \mathrm{cm}^{2}$ and give rise to corrosion penetrations of $1 \mathrm{mpy}$ or smaller.

In structures corroded in an active state, oxygen diffusion to the reinforcements was until fairly recently believed to determine the upper limit of corrosion rates. However, recently reported results cannot be accounted for on this basis [4-6] since $i_{\text {corr }}$ values higher than those expected from the $i_{\text {lim }}$ of oxygen diffusion in concrete are often measured.

As can be seen from Fig. 3a, in the presence of chloride ions, the type of curing to which the mortars were subjected resulted in two distinct levels of corrosion rates. Thus, the specimens cured in the steam chamber had $i_{\text {corr }}$ values between 0.1 and $1.0 \mu \mathrm{A} / \mathrm{cm}^{2}$, while those cured in the wet chamber yielded $i_{\text {corr }}$ values of $10 \mu \mathrm{A} / \mathrm{cm}^{2}$ and larger after 10 day's curing. Such a difference is too large for the two processes to develop via the same kinetic control. 
representa una diferencia demasiado elevada para que los procesos de corrosión respondan al mismo tipo de control cinético.

Los diagramas de impedancia obtenidos para las probetas con idénticas concentraciones de cloruros, pero curadas de manera diferente, confirman dos estados de corrosión muy distintos para ambas, hasta el punto de que el diagrama correspondiente a la probeta con cloruros curada en cámara de vapor se parece mucho más al correspondiente al estado pasivo (probeta sin cloruros), que al de otra probeta de idéntica composición curada en cámara húmeda. Si la difusión del oxígeno fuera la etapa controlante en ambos casos, dado que no se han encontrado diferencias de porosidad significativas para los dos tipos de curado, ambos deberían de conducir a velocidades de corrosión semejantes.

Independientemente del contenido en cloruros, las probetas curadas en cámara de vapor suelen dar $\mathrm{i}_{\text {corr }}<1 \mu \mathrm{A} / \mathrm{cm}^{2}$, asimilables a un control por difusión (figura 4). Curiosamente, se corroen en orden inverso al contenido en cloruros.

Las resistividades no ayudan a la comprensión de comportamientos tan dispares, pues las diferencias de la figura $2 c$ son atribuibles al distinto grado de saturación de los poros, que tiende, además, a igualarse con el transcurso del tiempo (figura 3c) y las diferencias obtenidas para el mismo tipo de curado (figura 4c) son perfectamente atribuibles a la dosificación en cloruros. Todo parece indicar que los dos tipos de curados aportan el agua suficiente para que tengan lugar las reacciones de hidratación del cemento.

Sin embargo la evolución de los $E_{\text {corr }}$ sí que resulta ilustrativa. En el estado pasivo (figura $2 b$ ), con la formación y crecimiento de las capas pasivantes, tiene lugar un ennoblecimiento progresivo del potencial y una disminución, también progresiva, de las velocidades de corrosión (figura $3 a$ ), en total acuerdo con lo habitual en los fenómenos de corrosión.

Sorprendentemente, las probetas trasvasadas de la cámara de vapor a la cámara húmeda manifiestan, durante los primeros 10 días de curado, un comportamiento contradictorio con la norma, general en corrosión, de que a potenciales más nobles correspondan menores velocidades de corrosión (figura 3b). Primeramente se produce un acusado descenso de los $E_{\text {corr }}$, simultáneamente con una disminución, también muy acusada, de las $i_{\text {corr }} y$, a continuación, un ennoblecimiento muy abrupto de los $E_{\text {corr }}$, acompañado de un gran aumento de las $i_{\text {corr }}$, en lugar del lógico descenso. Los hechos parecen apoyar la idea de que el proceso de corrosión se desarrolla de acuerdo con las etapas siguientes:
The impedance diagrams obtained for the specimans with identical chloride concentrations but cured differently confirm the need for rather different corrosion states, so much so that the diagram of the chloride-containing mortar specimens cured in the steam chamber is much more closely resenblant of that representative of the passive state (specimen without chlorides) than of another specimen with the same composition but cured in the wet chamber. If oxygen diffusion were the rate-determining step in both cases, the corresponding corrosion rates should be quite similar as no significant differences in porosity between the two were found.

Irrespective of their chloride content, the specimens cured in the steam chamber provided $i_{\text {corr }}$ values below $1 \mu \mathrm{A} \mathrm{cm}^{2}$, which are compatible with diffusion control (Fig. 4). Interestingly, they were corroded at a rate inversely proportional to their chloride content.

Such a dissimilar behaviour cannot be accounted for on the basis of the mortar resistivity. In fact, the differences shown in Fig. $2 c$ can be ascribed to differences in the degree of pore saturation, which, in addition, tend to disappear (Fig. 3c). Also, the differences for a given curing time (Fig. 4C) can be ascribed to those in the chloride content. Thus, everything seems to indicate that the two types of curing provided enough water for the hydration of cement to develop.

On the other hand, the changes in $E_{\text {corr }}$ are indeed highly revealing. In the passive state (Fig. 2b), as passivating layers form and grow, the potential gradually increases and the corrosion rates decrease concomitantly (Fig. 2a), consistent with typical observations on corrosion phenomena.

Surprisingly, the specimens transferred from the steam chamber to the wet chamber behaved contrary to the expectations during the first 10 days of curing; in fact, their corrosion rates did not decrease with increase in the potential (Fig. 3b). Thus, $E_{\text {corr }}$ initially decreased sharply as $i_{\text {corr }}$ also decreased markedly. This was followed by an abrupt increase in $E_{\text {corr }}$ and a marked increase -rather than the expected decrease - in $i_{\text {corr }}$. These findings seemingly support the assumption that the corrosion process taken place in the following steps: 

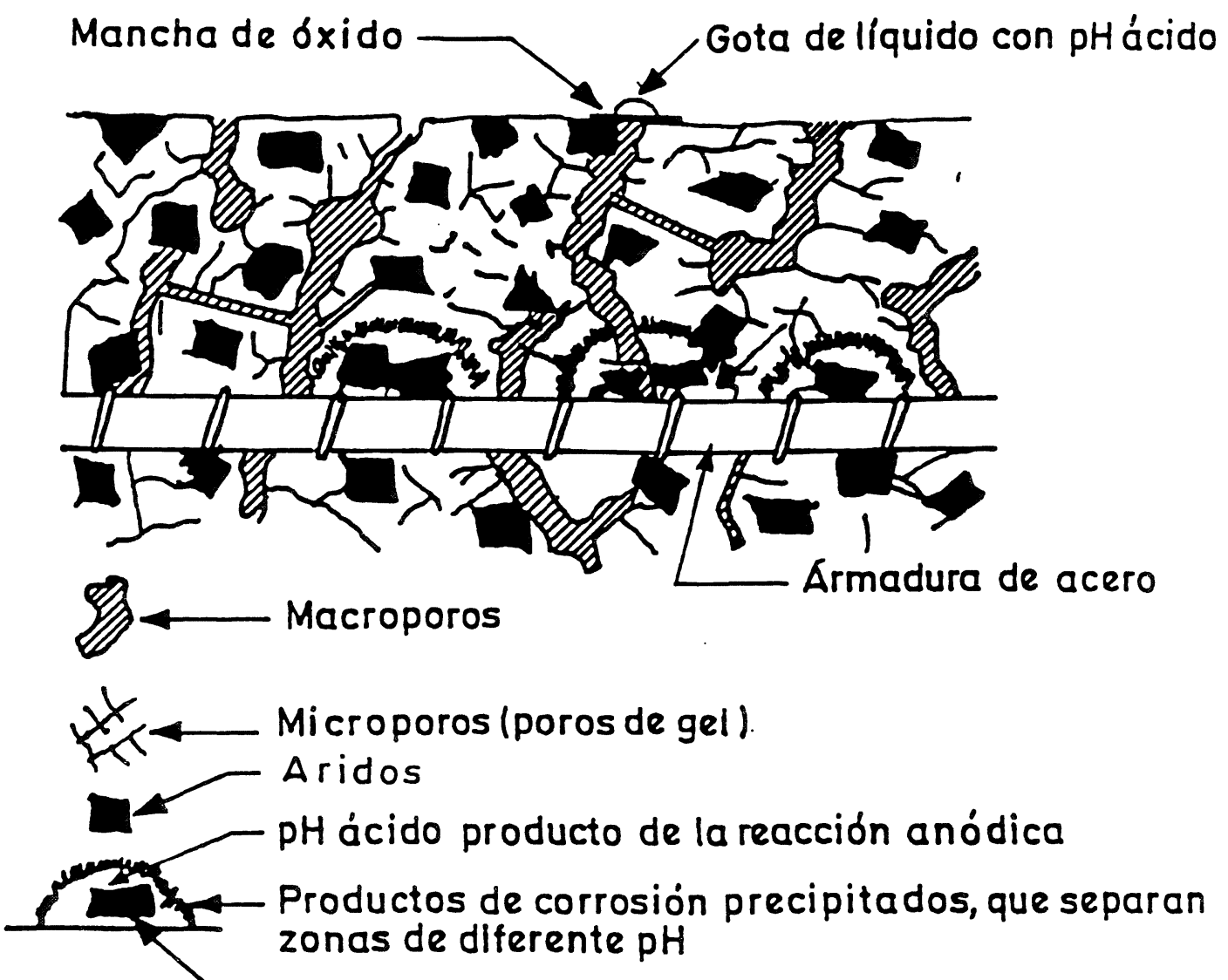

Resquicio geométrico en la interfase acero-agregado

Fig. 7.-Esquema ilustrativo de la propiedades químico-físicas del hormigón y su relación con el desarrollo de corrosión localizada en las armaduras.

1. Durante los primeros 3-5 días, tiene lugar una corrosión en estado activo, bajo control por difusión del oxígeno, lo que explicaría la progresiva y simultánea disminución del $E_{\text {corr }} y$ de la $i_{\text {corr }}$.

2. Con el traslado de la cámara de vapor a la cámara húmeda (sea en la primera semana o a los 40 días) comienza a producirse una cesión del agua de los poros al ambiente, comprobada gravimétricamente (figura 6) y estimada entre un 5 y $10 \%$ del volumen total de los poros.

3. Esta pérdida de agua afectaría preferentemente a los macroporos, cuyo equilibrio de condensación-evaporación es mucho más sensible a pequeñas variaciones en la presión de vapor de $\mathrm{H}_{2} \mathrm{O}$ que en el caso de los microporos y poros de gel. De esta forma, los macroporos se convertirían en canales de aireación preferente (figura 7), produciéndose la inversión en el sentido de desplazamiento de los $E_{\text {corr }}$.
Fig. 7.-Scheme illustrating the physico-chemical properties of concrete and their relationship to the development of localized corrosion in the reinforcements.

1. During the first 3-5 days takes place corrosion in the active state under control of oxygen diffusion, which would account for the gradual, simultaneous decrease in $E_{\text {corr }}$ and $i_{\text {corr }}$.

2. On transferral from the steam chamber to the wet chamber, either in the first week or after 40 days, water is released from the pores into the environment, which was checked gravimetrically (Fig. 6) and estimated to represent $5-10 \%$ of the overall pore volume.

3. This water loss would preferentially affect macropores, the condesation-evaporation equilibrium of which is much more sensitive to small changes in the water vapour pressure than are micropores and gel pores. In this way, macropores would be converted into preferential aeration channels (Fig. 7), thereby reversing the direction of $E_{\text {corr }}$ changes. 
4. Con la mayor oferta de oxígeno se produciría el fortalecimiento de las pilas de aireación diferencial, que podrían alcanzar varios centenares de $\mathrm{mV}$ en los resquicios,siempre presentes en materiales tan heterogéneos como el mortero y el hormigón.

5. Los resquicios se convertirían en ánodos locales fuertemente polarizados y se enriquecerían progresivamente en cloruros, para compensar eléctricamente el exceso de iones $\mathrm{Fe}^{2+}$ allí generados. Esto acarrearía una acidificación, también progresiva, de los resquicios por la hidrólisis ácida del $\mathrm{FeCl}_{2}$.

6. Aumento de la velocidad de corrosión, hasta que se establecen unas condiciones de $\mathrm{pH}$ e $i_{\text {corr }}$ estacionarias e independientes de la oferta de oxígeno, que se mantienen incluso en medios anaerobios.

El comportamiento durante el curado parece suceder de acuerdo con el mecanismo de acidificacióon local en el hormigón, propuesto recientemente [7]. La aparición ocasional pero repetida de exudados ácidos, con $\mathrm{pH}$ en torno a 2 , en las probetas con adiciones del 2 y $4 \%$ de $\mathrm{Cl}^{-}$, curadas en cámara húmeda a través de grietas o macroporos, apoya esta forma de pensar. Tales exudados pueden explicarse por fenómenos osmóticos, al fluir el electrólito de los poros hacia las zonas de máxima concentración salina (maxima corrosión) y, si existen vías de evacuación preferentes, conectadas con los resquicios ácidos, como pueden ser los macroporos que llegen a la superficie, aflorará a ésta un electrólito con la microquímica especial de tales zonas (figura 7).

El hecho de que las probetas con el máximo contenido de cloruros, el $6 \%$, exhiban menores velocidades de corrosión y no hayan mostrado nunca exudados ácidos, lejos de oponerse a este mecanismo lo confirma, pues la higroscopicidad del $\mathrm{NaCl}$ hace que, para las mayores concentraciones, la superficie del mortero aparezca siempre mojada, evitando que los macroporos actúen como canales de aireación preferencial.

\section{CONCLUSIONES}

En las estructuras de hormigón armado se produce una multiplicidad de fenómenos de corrosión, que responden, al menos, a tres tipos de control del proceso global de corrosión bien diferenciados:

- Un control por pasivación en hormigones no carbonatados y exentos de cloruros.
4. The greater availability of oxygen would reinforce differential aeration cells, which could reach a few hundred $m V$ at the crevices usually ocurring in such heterogeneous materials as mortar and concrete.

5. The crevices would become strongly polarized local anodes that would be gradually enriched with chloride in order to compensate electrically for the excess of $\mathrm{Fe}^{2+}$ ions generated in them. This would result in an also gradual acidification of the crevices by acid hydrolysis of $\mathrm{FeCl}_{2}$.

6. The corrosion rate would increase until stationary $\mathrm{pH}$ and $i_{\text {corr }}$ conditions were reachedirrespective of the oxygen supply. Such conditions would be preserved even in anaerobic media.

The behaviour during curing appears to be consistent with the recently reported mechanism for local acidification in concrete [7]. The occasional, but recurrent emergence of acid exudates with $\mathrm{pH}$ values of about 2 from the crevices and macropores of the specimens that were added 2 and $4 \% \mathrm{Cl}$ and cured in the wet chamber supports this assumption. The exudates can be ascribed to osmotic phenomena: the electrolyte flows from the pores to those zones with the maximum salt concentration (maximum corrosion) and, in the presence of preferential evacuation ways connected with the acid crevices (e.g. macropores connected with the surface), it reaches the outside as an electrolyte with the special microchemistry of such zones (Fig. 7).

The fact that the specimens with the maximum $\mathrm{Cl}$ content (6\%) had the lowest corrosion rates and never showed any acid exudates, far from being in contradiction with this mechanism, supports it: in fact, because of the hygroscopicity of $\mathrm{NaCl}$, the surface of the mortars containing the highest salt concentrations was always wet, thereby preveting macropores from acting as preferential evacuation channels.

\section{CONCLUSIONS}

Concrete structures undergo a variety of corrosion phenomena that take place via one of at least three distinct kind of controls of the overall corrosion process, namely:

\section{- In uncarbonated or no chlorides containing} concretes, corrosion is controlled by passivation. 
- Un control por difusión del oxígeno en estructuras que se corroen en estado activo, pero con escasas posibilidades de aireación desde los comienzos del proceso, de forma que se agote el oxígeno antes de que se produzcan acidificaciones locales fuertes.

- En casos especialmente desfavorables, la corrosión en estado activo, con suficiente oferta de oxígeno y cloruros, desemboca en la acidificación local de zonas de la interíase acero/mortero, pudiendo proseguir el fenómeno de corrosión aun sin el concurso del oxígeno. La repetida aparición de exudados muy ácidos confirma este mecanismo.

- Nimias diferencias en las condiciones de humedad del curado (relacionadas con el equilibrio de condensación capilar del agua en los macroporos del hormigón), tienen una decisiva influencia en la futura resistencia a la corrosión del refuerzo metálico, imponiendo uno u otro de los tipos de control propios del estado activo.
- In those structures that are corroed in an active state but with little likelihood of aeration from the beginning of the processes, corrosion is governed by oxygen diffusion so as to deplete it before any local acidification takes place.

- In those especially unfavourable cases where corrosion takes place in an active state characterized by a large enough supply of oxygen and chloride, acid $\mathrm{pH}$ values are reached locally, so corrosion can proceed without the concourse of oxygen. The recurrent appearance of very acidic exudates supports the occurence of this mechanism.

- Minimal differences in the humidity conditions of curing (related to the capillar condensation equilibrium in the concrete macropores) have a marked influence on the future corrosion resistance of the metallic rebars and dictate which of the typical mechanisms of the active state will prevail.

\section{REFERENCIAS}

[1] J. A. GONZÁLEZ: "Control de la corrosión. Estudio y medida por técnicas electroquímicas". Ed. CSIC, Madrid 1989. Capítulo I, p. 1-21.

[2] C. ANDRADE and J. A. GONZÁLEZ: Werk. U. Korr, 29, 515-519, (1978).

[3] J. A. GONZÁLEZ and C. ANDRADE: Br. Corros. J., 17, (1), 21-28 (1982).

[4] J. A. GONZÁLEZ, A. MOLINA, E. OTERO and W. LÓPEZ: Mag. Concr. Res., 42, (150), 23-27, (1990).

[5] F. J. MENDOZA, C. U. CANO and J. ÁVILA: Memorias IV Cong. Nac. de Electroquímica y Corrosión. Sociedad Mexicana de Electroquímica. México, D. F., p. 18, 1989.

[6] S. HSIEK and A. SAGÜES: Ext. Abstracts, 1st. Int. Cong. on Electrochem. Imp. Spectroscopy. Bombannes-Mabuisson, Carcans (Francia), Mayo de 1989. Paper C 2.5.

[7] E. OTERO, J. A. GONZÁLEZ, S. FELIÚ and W. LÓPEZ: 11th Int. Corros. Cong., Florence, April de 1990. Vol. 2, p. 2.459. 